\title{
Intelligence level in children with cerebral palsy (CP) at YPAC Medan
}

\author{
Abdul Mutholib Rambe, Amir Syarifuddin, Bistok Saing
}

\begin{abstract}
Abstrak
Telah dilakukan penelitian mengenai tingkat kecerdasan pasien anak penyandang kelumpuhan otak (CP) di Yayasan pembinaan anak cacad (YPAC) Medan, dengan menghubungkan antara jenis CP, derajat retardasi mental, serta jenis kelamin. Penelitian dilaksanakan secara potong lintang, meliputi semua pasien dengan CP yang terdaftar dalam buku registrasi poliklinik YPAC Medan antara Juli 1987-Juni 1998. Semua di antara 74 pasien yang diikutsertakan dalam penelitian ini mempunyai IQ di bawah rata-rata dan $62 \%$ di antaranya berjenis perempuan. Jenis yang paling banyak ialah tipe spastik (65\%), kemudian campuran (16\%), diskinetik (11\%) dan hipotonik (8\%). Secara keseluruhan, golongan CP campuran mempunyai derajat retardasi mental paling berat. Secara statistik terdapat hubungan bermakna antara jenis $C P$ dengan tingkat retardasi mental $(P<0.001)$, dan tak terdapat hubungan bermakna antara jenis CP dengan jenis kelamin. (Med J Indones 2002; 11: 242-5)
\end{abstract}

\begin{abstract}
Children with cerebral palsy has been investigated at YPAC (Yayasan Pembinaan Anak Cacat / Institute for Crippled Children) Medan to obtain the detailed description of patient's intelligence level referring to cerebral palsy types and to determine the relationship between palsy types and mental retardation level as well as to relate cerebral palsy types and sex. The study is cross-sectionally conducted involving all cerebral palsy patients listed in registration book of YPAC Policlinic Medan from July 1987 to June 1998. Of 74 patients participated in the study, all had IQ under average and $62 \%$ them were female. The most common type is spastic (65\%), followed by mixed (16\%), dyskinetic (11\%) and hypotonic (8\%), respectively. Overall, the mixed type had severe mental retardation. Statistically, there is a significant relationship between cerebral palsy types and mental retardation level $(p<0.001)$. There is no significant relationship between cerebral palsy types and sex. (Med J Indones 2002; 11: 242-5)
\end{abstract}

Keywords: cerebral palsy, intelligence level, children with $C P$

It is interesting to monitor the motor development because the change can be clearly seen. It is a gradual process beginning from the newborn to the adult following a regular pattern with predetermined sequence. Before more complex skills could be learned, the simple ones must be passed through. General and undirected movements became specific and directed. The motor development is a genetically programmed process. Environmental, racial, sexual and socio-cultural factors play little role in motor development. ${ }^{1,2}$

Cerebral palsy is a static encephalopathy that may be defined as a non progressive disorder of posture and movement resulting from a defect or lesion of the developing brain from mild to severe. ,3,4-7 $^{1,4}$ severity of motor development disabilities depend much on type, size and distribution of the cerebral

Department of Child Health, Medical School, University of North Sumatera/H. Adam Malik Hospital, Medan, Indonesia lesion as well as on the patient's intelligence. ${ }^{1,3}$ The exact time when the growing brain reaches the adult size is still a controversy. Some authors suggested the age of 2 years; other investigators reported the brain can still increase in weight until the age of 5 to 8 years. ${ }^{3}$

Cerebral palsy is also commonly associated with a spectrum of developmental disabilities, including mental retardation, epilepsy, visual, hearing, speech, cognitive and behavioral abnormalities. ${ }^{1,3,5}$ Intellectual problem in the form of mental retardation often occurred in cerebral palsy. ${ }^{5,8}$ According to Brett, ${ }^{9}$ there is no significant relationship between cerebral palsy types and intelligence level. But most children with spastic-type cerebral palsy had mental abilities under average, and their performance showed the subnormal mental symptoms. ${ }^{8}$ This study is aimed to obtain a detailed description of intelligence level for children with cerebral palsy based on the type, to 
determine the relationship between cerebral palsy types and mental retardation level as well as to relate cerebral palsy types and sex for children with cerebral palsy at YPAC Medan.

\section{METHODS}

This investigation is a cross sectional study carried out from October to November 1998 involving all children with cerebral palsy listed in the registration book of YPAC Policlinic Medan since July 1987 to June 1998. The participants were 2-14 years old. The children's age was determined as follows: 30 days equal to a month; 12 months is a year. The children's aged less than 15 days was neglected, more than 15 days were counted as one month. The patients' data were collected from medical records including name, age, sex and cerebral palsy types. Clinically cerebral palsy was classified as follows: (1) spastic; (2) dyskinetic; (3) hypotonic; (4) ataxic and (5) mixed types. ${ }^{10}$ Written informed consent were obtained from the parent or guardian and the patient's intelligence level was measured by a psychologist using the StanfordBinet method. The quantitative value was converted into qualitative results by classifying IQ level into: severe (IQ $<35$ ), intermediate (IQ = 36-51), mild ( IQ = 52-67) and borderline $(\mathrm{IQ}=68-83)$ mental retardation. ${ }^{11}$

The statistical analysis was done using a computer with SPSS for windows program. KolmogorovSmirnov goodness of fit test was used to examine whether or not the data is distributed normally. The relationship between two qualitative variables was analyzed using chi-square test (confidence level 95\%; $p<0.05)$.

\section{RESULTS}

There were 86 children with cerebral palsy recorded in the patient registration book of YPAC Policlinic Medan from July 1987 to June 1998 with the age between 2-14 years (mean 7.9; SD 2.29). Only 74 cases of them $(80 \%)$ could be included in the study, consisting of 46 cases (62\%) girls and 28 cases (38\%) boys. Twelve children not included from the study consisted of : 5 uncontrolled and unclear cases; 2 had moved to other areas and 4 whose IQ could not be tested. All IQ were below average. The distribution of intelligence level examination showed : severe 20 cases (27\%), intermediate 24 cases (33\%), mild 20 cases (27\%) and borderline 10 cases (13\%) of mental retardations.

Based on the cerebral palsy classification, spastic, dyskinetic, hypotonic and the remaining mixed types were $48(65 \%), 8(11 \%), 6(8 \%)$ and $12(16 \%)$ cases, respectively. The characteristics of cerebral palsy patients with mental retardation can be seen in table 1 .

Table 1. Characteristics of study subjects

\begin{tabular}{lccc}
\hline \multicolumn{1}{c}{ Characteristics } & Subjects & IQ & $(\%)$ \\
\hline Age (yr), mean (SD) & 7.9 & & - \\
& $(2.99)$ & & \\
Sex: & & & 38 \\
- Male & 28 & & 62 \\
- Female & 46 & & \\
Cerebral palsy types: & & & 65 \\
1. Spastic & 48 & & 11 \\
2. Dyskinetic & 8 & & 8 \\
3. Hypotonic & 6 & & 16 \\
4. Mixed & 12 & & \\
Mental retardation level : & & & \\
1. Borderline & 10 & $68-83$ & 13 \\
2. Mild mental retardation & 20 & $52-67$ & 27 \\
3. Intermediate mental & 24 & $36-51$ & 33 \\
$\quad$ retardation & & & \\
4. Severe mental retardation & 20 & $<35$ & 27 \\
\hline
\end{tabular}

$\mathrm{SD}=$ Standard deviation; $\mathrm{IQ}=$ Intelligence quotient

In the 48 cases of spastic type cerebral palsy, severe mental retardation was found in 4 cases (8\%) only. Mild mental retardation was found in 20 cases $(42 \%)$; the remaining were intermediate and borderline mental retardation, 14 (29\%) and 10 (21\%) cases, respectively. From 6 cases of hypotonic type, severe and intermediate mental retardation were $2(33 \%)$ and $4(67 \%)$ cases, respectively. In the 8 dyskinetic group, there were cases of mild and borderline mental retardation; severe mental retardation in this dyskinetic type was seen in 2 cases (25\%); the remaining $6(75 \%)$ were intermediate cases. All of 12 mixed type generally showed severe mental retardation. Statistical analysis, discovered significant relationship between cerebral palsy types and mental retardation level (Table 2; $p<0.001$ ).

The majority of patients were female with spastic type $63 \%$, hypotonic $67 \%$, dyskinetic $63 \%$ and mixed $58 \%$. Statistically, there was no significant relationship between cerebral palsy types and sex (Table $3 ; p>0.05$ ). 
Table 2. The relationship between cerebral palsy types and mental retardation level

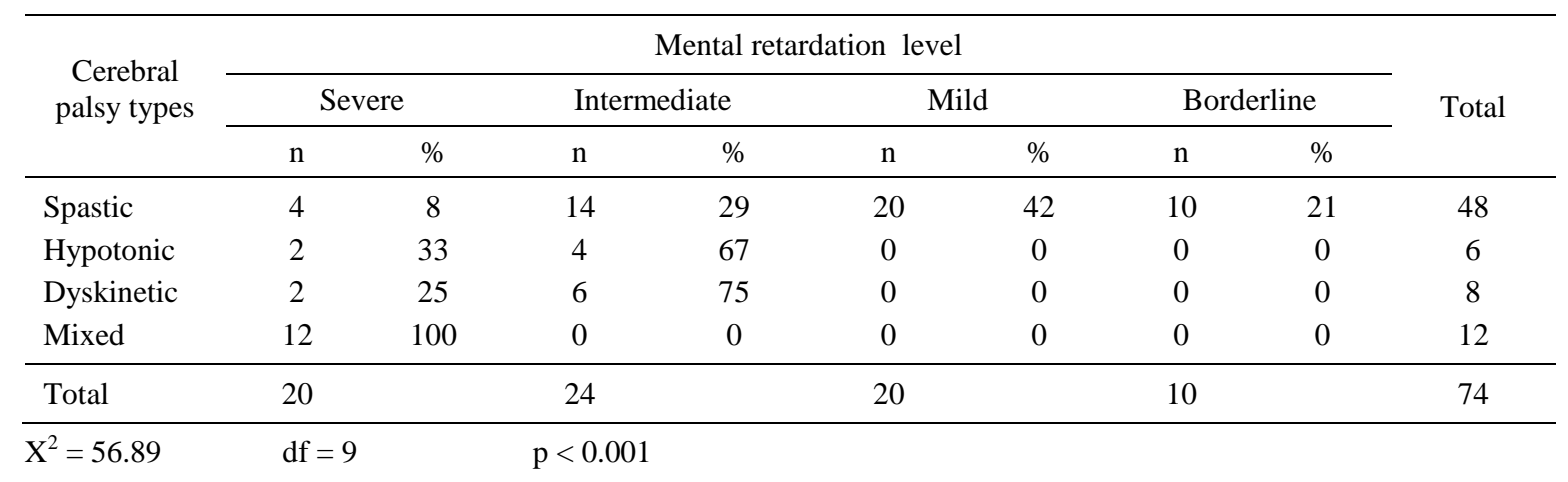

Table 3. The relationship between cerebral palsy types and sex

\begin{tabular}{|c|c|c|c|c|c|c|c|c|c|c|}
\hline \multirow{3}{*}{ Sex } & \multicolumn{8}{|c|}{ Cerebral palsy types } & \multirow{2}{*}{\multicolumn{2}{|c|}{ Total }} \\
\hline & \multicolumn{2}{|c|}{ Spastic } & \multicolumn{2}{|c|}{ Hypotonic } & \multicolumn{2}{|c|}{ Dyskinetic } & \multicolumn{2}{|c|}{ Mixed } & & \\
\hline & $\mathrm{n}$ & $\%$ & $\mathrm{n}$ & $\%$ & $\mathrm{n}$ & $\%$ & $\mathrm{n}$ & $\%$ & $\mathrm{n}$ & $\%$ \\
\hline Female & 30 & 63 & 4 & 67 & 5 & 63 & 7 & 58 & 46 & 62 \\
\hline Male & 18 & 37 & 2 & 33 & 3 & 37 & 5 & 42 & 28 & 38 \\
\hline Total & 48 & & 6 & & 8 & & 12 & & 74 & 100 \\
\hline $\mathrm{X}^{2}=0.13$ & $\mathrm{df}=$ & & $\mathrm{p}<$ & & & & & & & \\
\hline
\end{tabular}

\section{DISCUSSION}

In this study, severe mental retardation was $27 \%$ or equal to the previous other study; ${ }^{12}$ mild and intermediate were $27 \%$ and $33 \%$ of our cases respectively. Moe and Seay ${ }^{12}$ reported that mild to intermediate and severe mental retardation were found in $26 \%$ and $27 \%$, of their sample respectively. The incidence of mental retardation related to the severity of cerebral palsy.

The number of cerebral palsy patients with mental retardation in female is larger than male patients, 46 cases $(62 \%)$ vs 28 cases $(28 \%)$ (Table 1$)$, although statistically, the difference is not significant (Table 3, $p>0.05)$. It differs from another study conducted by Franky (1994) (cited by Soetjiningsih) that obtained the opposite results; $58,3 \%$ cerebral palsy patients were boys.

According to Monar (cited by Soetjiningsih), the spastic-type was the most common type, followed by mixed, dyskinetic and hypotonic types, respectively. ${ }^{3}$ The highest percentage of cerebral palsy in this study is spastic found in 48 cases $(65 \%)$, followed by mixed in 12 cases (16\%), dyskinetic in 8 cases (11\%), hypotonic in 6 cases $(8 \%)$. The sequence of the frequency of the various types of $\mathrm{CP}$ is similar to Monar's report.

Statistically, mental retardation level is significantly related to cerebral palsy types. Severe mental retardation is more commonly found in mixed, less in spastic and rare in hypotonic, dyskinetic and ataxic types.

This study showed that all spastic-type patients have subnormal intelligence level which agrees with Mohsen's report. ${ }^{8}$ Other studies reported that relationship was found between mental retardation level and the clinical severity ${ }^{13}$ which is similar to our findings (Table 2; $p<0.001$ ). In spastic diplegia, severe mental retardation was rarely found compared with other types. Almost $25 \%$ spastic hemiplegic patients had cognitive abnormality including mental retardation. ${ }^{5}$ Spastic quadriplegia was closely related with mental retardation, and almost $90 \%$ were severely retarded. ${ }^{13,14}$ Ingram (cited by Weil and Levin) ${ }^{13}$ reported that none of the children with spastic quadriplegia were educable. Unfortunately, in 
this study, cerebral palsy types are not specified in more detail. Crothers and Paine (cited by Weil and Levin) ${ }^{13}$ reported that $65 \%$ extra pyramidal-type had intelligence level over 70 and $45 \%$ of them had an IQ 90 or more. Mixed type cerebral palsy, caused by combined multiple and large cerebral lesion, is specifically related to the more complicated cases including sensory deficit, seizures and cognitive/ perception abnormalities. ${ }^{15}$ If cerebral palsy is accompanied by seizures, intelligence will be statistically lower. ${ }^{6}$ Children with spastic quadriplegia type are often associated with athetosis and classified as mixed type. ${ }^{5}$ In this study, mental retardation level is significantly related to cerebral palsy types. Different intelligence levels can be found in spastic type, but the most common were mild $42 \%$, followed by intermediate $29 \%$, borderline $21 \%$ and the remaining severe mental retardation $8 \%$. In the dyskinetic type, three fourth of all cases were intermediate and the remaining were severe mental retardation. Two third of cases, in the hypotonic type, were intermediate, and one third severe mental retardation. Most mixed type $\mathrm{CP}$ patients had severe mental retardation. This study showed that the incidence of severe mental retardation in the spastic type was low $(8 \%)$, whereas mild mental retardation was high (42\%); intermediate mental retardation and borderline were $29 \%$ and $21 \%$, respectively. Two third of the cases in the hypotonic type were intermediate, and the remaining, severe mental retardation. In the dyskinetic type, three fourth of the cases were classified as intermediate and other mild mental retardation. All mixed type cases had severe mental retardation. Statistically, significant relationship between cerebral palsy types and the level of mental retardation was encountered $(p<0.001)$. No significant relationship between cerebral palsy types and sex was found.

\section{REFERENCES}

1. Passat J. Kelainan perkembangan motorik. In: Pusponegoro HD, Passat J, Mangunatmadja I, Soetomenggolo TS, Ismael $\mathrm{S}$, editors. Neurologi anak dalam praktek sehari-hari. Naskah lengkap PKB Ilmu Kesehatan Anak XXXIV. FKUI; 21-22 April 1995; Jakarta: Balai Penerbit FKUI, 1995.

2. Manoeroeng SM. Memasyarakatkan tumbuh kembang anak dalam rangka meningkatkan kualitas. Pidato pengukuhan guru besar Ilmu Kesehatan Anak FK USU Medan, 1992.

3. Soetjiningsih. Palsi serebralis. In: Ranuh IG.N Gde, editor. Tumbuh kembang anak. Jakarta: EGC. 1995. p.223-35.

4. Hutton JL, Cooke T, Pharoah POD. Life expectancy in children with cerebral palsy. BMJ 1994; 309;431-5.

5. Haslam RHA. Cerebral Palsy. In: Behrman RE, Kliegman RM, Nelson WE, Arvin AM, editors. Nelson textbook of pediatrics. $15^{\text {th }}$ ed. Philadelphia: Saunders, 1996.p.1713-4.

6. Wollack JB, Nichter CA. Static encephalopathies. In: Rudolph AM, Hoffman JIE, Rudolph CD, editors. Rudolph's pediatrics. $20^{\text {th }}$ ed. USA: Prentice-hall inc., 1996. p.1892-7.

7. Passat J. Kelainan perkembangan. In: Soetomenggolo TS, Ismael S, editors. Buku ajar Neurologi anak. Ikatan Dokter Anak Indonesia. Jakarta: Balai Penerbit FKUI, 1999.p.115-23.

8. Mohsen Z. Pediatrics. $3^{\text {rd }}$ ed. Boston: Little Brown and co, 1984. p.49.

9. Brett EM. Cerebral palsy, perinatal injury to the spinal cord and brachial plexus birth injury. In: Brett EM, editor. Paediatric neurology. London: Churchill livingstone, 1983. p.245-70.

10. Baird HW, Gordon EC. Neurological evaluation of infants and children. Philadelphia: JB Lippincott co, 1983.p.107-17.

11. Wechsler D. The measurement of adult intelligence. $3^{\text {rd }}$ ed. Baltimore: Williams \& Wilkins, 1994.p.190.

12. Moe PG, Seay AR. Cerebral palsy. In: Hay WW, Groothuis JR, Hayward AR, Levin MJ, editors. Current pediatric diagnosis and treatment. $12^{\text {th }}$ ed. USA: Prenticehall Int, 1995. p.783-4.

13. Weil ML, Levin M. Perinatal asphyxia and trauma. In: Menkes JH. Textbook of child neurology. $5^{\text {th }}$ ed. Baltimore: Williams \& Wilkins, 1995.p.325-78.

14. Eligibility. Available from: http://www.farnorthernrc.org/eligibly.html.

15. Lipson T. Cerebral palsy, brain damage, blame and defensive obstetrics: Time for U-turn? J Pediatr Child Health 1991; 27:201-2. 